\title{
Articles
}

ALEKSANDER GORZELAK

DOI: $10.5604 / 00441600.1232982$

JUSTYNA HERDA-KOPAŃSKA

JACEK KULAWIK

MICHAE SOLIWODA

BARBARA WIELICZKO

Institute of Agricultural and Food Economics

- National Research Institute

Warsaw

\section{CONTROVERSIES OVER THE EUROPEAN VALUE ADDED CREATED BY CAP}

\begin{abstract}
From the beginning of the financial crisis - 2008/2009 - the EU entered an unprecedented period of very serious shocks. These problems first affected the economy (weak and highly variable growth with times of rather shallow recession, high unemployment, especially among young people) and then they spread to the bank sector and the national budgets. Consequently, several of the old EU countries, belonging to the euro area, became - in fact - insolvent. To make the matters worse, southern Europe was hit by a huge wave of immigration, Russians took over the Crimea, a war erupted in Donbas and Donald Trump, who can considerably weaken the NATO, won the US presidential elections. The subsequent attempts at solving these mini-crises were often delayed, not very daring and erratic. Thus, it comes as no surprise that the crisis, ultimately, started to affect also the sociopolitical and institutional areas, which is manifested in growing distrust of the Europeans in the Community institutions and liberal democracy. This, in turn, resulted in widespread populism, national and regional egoism and disintegration tendencies. Brexit is one of the first effects of the process along with the concerns that other members of the EU may take similar decisions
\end{abstract}


which would be tantamount to its breakup. In these circumstances, convincing validation of further existence and development of the Community requires great intellectual, political and organisational effort, and then finding effective channels to reach as broad as possible circle of responsible citizens with the proposals, recommendations and ready application solutions to help them regain trust in the meaning of the European project and possibilities of functioning in the double national and European identity. It would be perfect to make the mended EU more democratic, i.e. to actively engage in the process the very Europeans and not only techno- and Eurocrats. One of the more interesting concepts, at the moment, seems to be the European added value, which - in a nutshell, means a sum of extra benefits obtained on account of integration against the effects resulting from the national socio-economic policy. It is possible to describe this value and, to some extent, even to quantify it for all areas of the European integration. However, the paper is restricted only to the CAP, focusing on methodological, environmental and climate, innovation and investment issues, and a set of key budget problems.

Keywords: European Added Value, agricultural finance, environmental and climate policy, Common Agricultural Policy.

JEL Cods: D62, D78, E62.

\section{Definition, classification and calculation problems}

The term "European Added Value" appears increasingly more often in the context of subsequent EU debates on multiannual financial framework. The high added value created by the EU expenditure is to be the key justification for the EU taxpayers to incur charges for the EU. The European Added Value (EAV) means the additional value obtained because a given measure was not taken at the level of Member States but at the European Union level. The very fact of determining a common stand for all Member States on a given issue can be considered added value, since it creates uniform framework for action and ensures operation of the EU common market which constitutes the crucial element of the EU added value, also as regards agriculture. Simultaneously, the CAP and measures related thereto in the field of public health protection regarding food products and also plant and animal health rules ensure uniform food production standards, which allows for reduction of transaction costs of trade between countries comprising the EU. This is reflected in the trade structure of the EU Member States, where trade in goods with other EU countries is higher than with third countries ${ }^{1}$.

However, the issue of separating the added value under the effects of implemented measures should be noted. It is even difficult to determine how respec-

\footnotetext{
${ }^{1}$ The only exception is the United Kingdom, which noted a higher value of trade in goods for non-EU countries (Eurostat, 2016).
} 
tive countries would react to a given problem and whether or not independent actions taken by them would contribute more to greater efficiency and effectiveness of the implemented policy. However, in such a case the effects would be limited to a given country only, and they would probably be barely visible at the level of the entire EU or even negative from the perspective of developing trade and execution of the fundamental freedoms that are at the grassroots of the Community functioning.

It is also necessary to highlight that recognising the problem and hammering out policy instruments in a given field at the EU level do not exclude the possibility of entrusting to the Member States the task of implementing the solutions on their own territories. In this case, the European Added Value can be both strengthened and weakened by quality of the national institutions, which in a given country are responsible for the EU policy implementation. This represents an additional difficulty in determining the European Added Value because some actions taken at the EU level can be better matched to the institutions, legal culture and traditions of some Member States than others.

The European Added Value is expressed also at the level of international cooperation with third countries. When acting as a single entity representing only one stand, it is easier to get the desired impact on decisions taken at such forums as the World Trade Organization or to arrive at an advantageous solution in the process of negotiating bilateral or multilateral trade agreements.

The added value generated by involvement of the European Union funds should be measured at the stage of proposing the shape of common policies. According to Molino and Zuleeg (2011), the process of estimating the European Added Value should cover the following stages:

1) Conceptualisation of a justification for the taken actions;

2) Definition of the best management structure covering the administrative level, form of cooperation with other entities and possible scope of their integration;

3) Selection of the most effective instruments of action.

The papers prepared by the European Commission draw attention to two principles of the added value - principle of additionality and principle of complementarity (European Commission, 2001). The former is linked to the principle of subsidiarity which states that the EU can take up actions only in areas, where actions implemented at the Community level are not the responsibility of Member States. The principle of additionality is mostly about the fact that the EU funds are not to replace the funds of Member States, while complementarity points out that involvement of public funds is to bring greater effects than those which could have been achieved without them.

At the level of determining the European Value Added as ex-ante analysis of validity of spendings from the EU budget, it should be helpful to apply assessment based on the concept of Figueira (2009), which puts forward twelve criteria grouped in four thematic blocks (Fig. 1). 


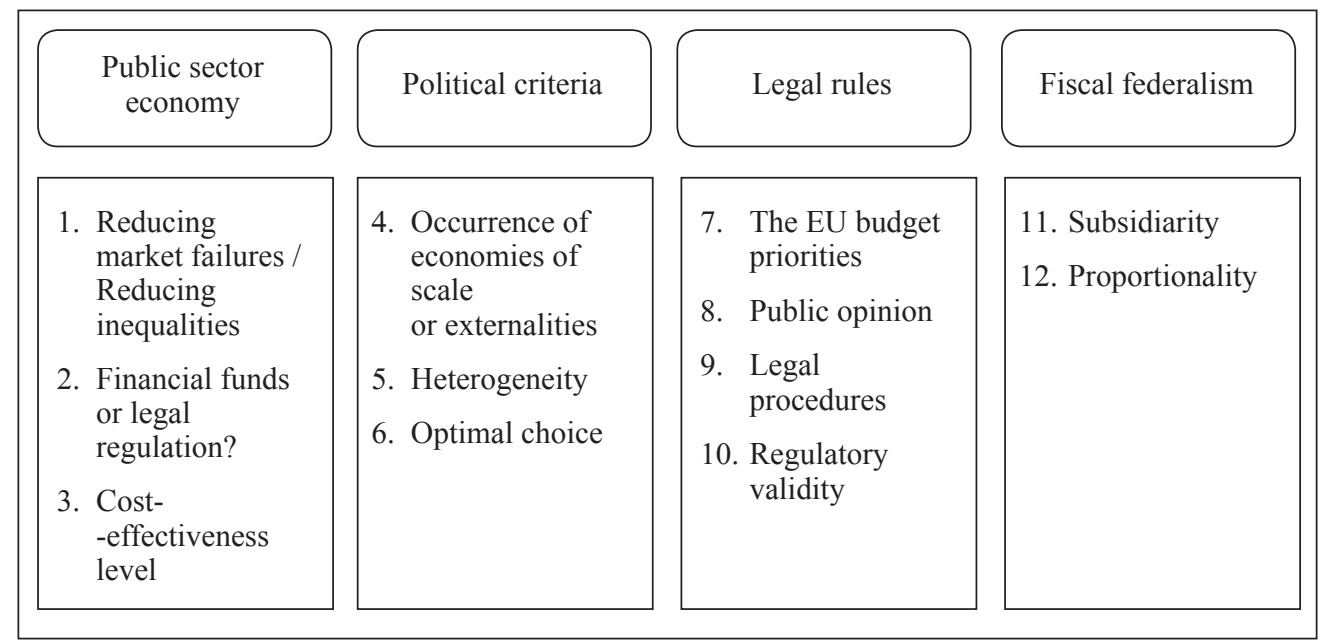

Fig. 1. Criteria of involvement of the EU funds.

Source: Figueira (2009).

The European Added Value is difficult to define and rather unclear. The concept was underlined in the discussions related to the EU budget review in 2010, although it had appeared in the debate much earlier (Ferrer and Kaditi, 2008). It justified the expenditures which would have been needed to implement European (transnational) level objectives. Table 1 presents this category from the perspective of scientific policy. It needs to be noted that along with refinement of public policy instruments (also agricultural policy), including launching new Framework Programmes, the EAV conceptual range has much extended. The newest approach considers also the contribution to the implementation of "the pan-European" social objectives and greater engagement in the implementation of the many EU policies.

In conclusion, it can be said that the concept of the European Added Value is very complex and still poorly recognised. The concept is yet at the stage of formulation and can be referred only to the relationship between objectives and results, estimating the value of an action jointly taken at the EU level against actions taken at lower levels (Vullings et al., 2014). At the same time, this category continues to be a rather political one (Report..., 2016) which can be also explained by lack of consensus as regards its understanding and measurement. 
Table 1

European Added Value from the perspective of scientific policy-matrix approach

\begin{tabular}{|c|c|c|c|c|c|c|c|}
\hline $\begin{array}{l}\text { Categories of dimensions } \\
\text { of the European Added Value }\end{array}$ & \begin{tabular}{|c|} 
FP1 \\
$84-88$
\end{tabular} & $\begin{array}{l}\text { FP2 } \\
87-91\end{array}$ & \begin{tabular}{|c|c|} 
FP3 \\
$90-94$
\end{tabular} \mid & $\begin{array}{c}\text { FP4 } \\
95-98\end{array}$ & $\begin{array}{c}\text { FP5 } \\
\text { 08-02 }\end{array}$ & $\begin{array}{l}\text { FP6 } \\
02-06\end{array}$ & $\begin{array}{c}\text { FP7 } \\
07-13\end{array}$ \\
\hline $\begin{array}{l}\text { The scale of the problem is too extensive } \\
\text { to be handled by a single country }\end{array}$ & & & & & & & \\
\hline $\begin{array}{l}\text { Financial benefits would be an added value / } \\
\text { synergy for the entire approach }\end{array}$ & & & & & & & \\
\hline $\begin{array}{l}\text { Unification of complementary approaches } \\
\text { to handle European scale problems }\end{array}$ & & & & & & & \\
\hline Cohesion of product markets & & & & & & & \\
\hline $\begin{array}{l}\text { Unification of Science and Technology across } \\
\text { borders of Member States }\end{array}$ & & & & & & & \\
\hline Promotion of uniform laws and standards & & & & & & & \\
\hline $\begin{array}{l}\text { Mobilising the EU potential at the European } \\
\text { and global level by coordinating the national } \\
\text { and the EU programmes }\end{array}$ & & & & & & & \\
\hline Involvement in the EU policy implementation & & & & & & & \\
\hline $\begin{array}{l}\text { Contribution to implementation of societal } \\
\text { objectives }\end{array}$ & & & & & & & \\
\hline $\begin{array}{l}\text { Exploiting the opportunities for the developme } \\
\text { of European science, technology and industry }\end{array}$ & & & & & & & \\
\hline $\begin{array}{l}\text { The EU structures of research } \\
\text { and development units }\end{array}$ & & & & & & & \\
\hline $\begin{array}{l}\text { Better quality by exposure of the EU to wider } \\
\text { competition (international approach) }\end{array}$ & & & & & & & \\
\hline
\end{tabular}

Key: FP - Framework Programme in relevant timeframe.

Source: adapted from a table by Arnolds, 2012, as in: Vullings et al., 2014, p. 22.

\section{CAP versus support to investments and innovations in the agricultural sector}

It is hard to unambiguously assess the EU agricultural policy from the perspective of efficiency of investment and innovation support in the agricultural sector. This results, above all, from the fact that this policy has not yet been directly assigned such objectives, and thus its instrumentation was not and still is not targeted at results in this field. This does not mean, however, that the implemented actions are not translated into the level of investments and innovations 
in agriculture. These tasks are implemented indirectly, though, and therefore it may be considered that effects in the scope are obtained "by the by" only.

Concurrently, it has to be emphasised that investment support under the so-called $2^{\text {nd }}$ pillar of the CAP is the largest part of the joint budget of all rural development programmes implemented in the current programming period (RDP 2014-2020). To this end - Measure M04 "Investments in fixed assets" - respective Member States have allocated from 2.95\% (Denmark) to $48.63 \%$ (the Netherlands) of their total funds under RDP 2014-2020 (Wieliczko, Kurdyś-Kujawska and Herda-Kopańska, 2016), which simultaneously shows freedom in adjustment of the budget instrumentation and structure of the programme. The case was similar in the former programming period when as much as EUR 8.7 billion of funds from the EU budget under the RDP 2007-2013 was earmarked for modernisation investments executed in ca. 380 thousand farms, which in turn translated into capital spending of the entities reaching EUR 25 billion $^{2}$. Apart from funds directly targeted at investments aon farms, investments are also supported indirectly through direct payments. Although these funds do not have a predetermined target, they affect the level of investments in the sector by increasing the farm income and, consequently, also their credit rating.

As for efficiency of support for investment in the EU agriculture under the CAP, it is difficult to draw clear-cut conclusions. The problem is still poorly recognized and estimates are very sensitive to selection of a research method. According to results of research held at the request of the European Commission by the consortium composed of Metis, WIFO and AEIDL, efficiency of investment support measured by a change in gross value added is highly varied. In Austria it was estimated that the change in the value on farms of beneficiaries of measure 121 "Support for investments at farms" amounted to 37\%, and in Poland - only $20 \%$, while a change in labour productivity, respectively: $9 \%$ and $3.4 \%$ (Metis, WIFO and AEIDL, 2014).

Innovation support from public funds is a very hard task, because the process of generating and implementing innovations is a very comprehensive one. Support for innovations under CAP was, until recently, focused on educational issues - trainings and availability of agricultural advisory services. Whereas support for investments realised at farms contributed to implementation of new technological solutions. In the present programming period, the need to catalyse the process of innovation creation and implementation is more strongly highlighted in CAP. A key element to innovation support is EIP-AGRI ${ }^{3}$, i.e. agricultural innovation partnership, which is a component of actions executed in relation to the Europe 2020 strategy. The EIP-AGRI is tasked with integration

\footnotetext{
${ }^{2}$ European Commission (2015). EU agriculture spending focused on results. Retrieved from: http:// ec.europa.eu/agriculture/cap-funding/pdf/cap-spending-09-2015_en.pdf (access date: September 2015).

${ }^{3}$ Further information on the EIP-AGRI and former activities undertaken by the partnership on the initiative's website: http://ec.europa.eu/eip/agriculture/en.
} 
of agriculture-based innovation environments and funds from various sources to execute projects aimed at creation of innovations.

It seems that it is too early to assess the role of the EIP-AGRI or the Community-Led Local Development in innovation generation and implementation. Undoubtedly, the issue of innovation should be one of the key elements of the future solutions in the field of agriculture support policy in the EU, especially in the context of inclusion of the sector in creating circular economy.

\section{CAP versus ecological, environmental and climate issues}

The impact of CAP on the natural environment changes systematically. Also support under the 1st pillar of CAP becomes increasingly more linked to the environment. First, cross-compliance requirements appeared and now the so-called greening. This is not yet a very efficient and effective mechanism of exercising a positive impact on climate and the environment, but it should be expected that it will be gradually perfected. What should be also mentioned, is the research conducted by IEEP (Baldock et al., 2016), which indicated that membership in the EU has been, in general, beneficial for the natural environment of the United Kingdom, which suggests that the CAP also had such an impact as it was in the best position to influence its condition. This largely resulted from taking up subsequent important environmental problems and implementing instruments referring to the issue in the EU policy.

The literature poorly covers the issue of EAV in the context of spending involved in mitigating the effects of climate change. Most of the former empirical studies highlight the existence of the added value in connection to the problem of overcoming negative externalities, using economies of scale and adjusting to other political priorities. Climate changes are cross-border in their nature, thus it is not possible to tackle their negative effects by numerous uncoordinated public polices of respective Member States. Additionally, governments of the EU countries usually understate the amount of funds allocated to actions involved in policy, mainly climate and energy policy, pointing simultaneously to the global nature of the reasons for climate change. Moreover, the existence of EAV in climate and energy policy is evidenced by the possibilities of using resources and benefiting from experts' knowledge at the transnational level. Adaptation measures involved in the response of the EU to climate change can be treated as public goods, because the Community residents (as well as, to a large extent, residents of neighbouring countries and enclave countries like Switzerland) cannot be excluded from the effects of impact of the climate policy instruments (Medarova-Bergstrom, Volkery and Baldock, 2012).

It is easy to undermine the argument on the negative impact of CAP on the climate and the environment, and its focus on intensification of agricultural production. Firstly, payment under the 1st pillar is hedged with meeting the cross-compliance criteria. Secondly, CAP 2014-2020 features a "superstructure" 
in the form of greening, and packages under RDP which motivate farmers to respect the environmental targets (e.g. LFA payments) ${ }^{4}$.

The basic source of greenhouse gas emissions in agriculture is animal production, especially production of ruminants. It will not be, however, easy to change the situation. But on a global scale, it is not the EU agriculture that will pose the most serious threat but the Asian and African communities, as far as their incomes will increase, thus causing a growth in meat consumption. The EU indicative targets concerning the share of biofuels contribute in an indirect manner to climate change, when they are implemented by import of components from the developing countries where it is linked to e.g. deforestation. The same mechanism is in play for fodder import to the EU. On the other hand, photosynthesis taking place in field crops binds carbon dioxide and the genetic progress and progress in farming technologies may significantly increase the efficiency of photosynthesis. The simplified tillage system and precision agriculture can also, at least, mitigate the climate change. Industrial agriculture is among the types of farming with the highest intensity of carbon dioxide emissions per final demand unit per means of production used therein (Perman, Ma, Common, Maddisson and McGilvray, 2011). Subsidies can increase the effect, while actual sustainability can decrease it. However, the newest research by Bennetzen, Smith and Porter (2016), mentioned by Wieliczko (2016), indicates that "in general, the most intensive and industrialised production systems are characterised by the lowest emission level per agricultural production unit" (expressed as a kg equivalent of $\mathrm{CO}_{2}$ per $\mathrm{GJ}$ of production).

The problem of CAP impact on climate and the environment should be considered from two perspectives. On the one hand, the agricultural sector was the emitter of greenhouse gasses (GHGs), and, on the other, the remaining sectors of the economy are also responsible for intensification of the greenhouse effect, such as power industry, transport or - to a lesser extent - industrial processing. In 2012, the agricultural sector in the EU (EU-28) Member States accounted for the emission of over $10.3 \%$ of greenhouse gasses to the atmosphere, while power industry (including transport) emitted $59.6 \%$ of carbon dioxide. The agricultural sector has a relatively low - as compared to other sectors - share in emission of the key greenhouse gas, i.e. carbon dioxide. The most important issue is consideration of the impact of nitrous oxide $\left(\mathrm{N}_{2} \mathrm{O}\right)$ and methane $\left(\mathrm{CH}_{4}\right)$. Emission of the first from the listed chemical compounds is created as a result of microbiological transformations of mineral and organic nitrogenous fertilis-

\footnotetext{
${ }^{4}$ According to research by Italian agro-economists, Ciliberti and Frascarelli (2015), greening of direct payments - as an "innovation" in CAP - strengthened the use of environment-friendly practices in the agricultural sector. The structure of the scheme of providing financial aid is favourable for medium acreage farms (in Polish conditions). This results from the degressivity mechanism, area limit in case of merging payments (e.g. agri-environmental payment) or reduction in the amount of granted single area payment (SAP) up to EUR 150 thousand per farm.
} 
ers and methane in the soil. It should be added that the $\mathrm{N}_{2} \mathrm{O}$ emissions constitute a half of all the agricultural emissions. The $\mathrm{CH}_{4}$ emissions are mainly the result of digestive processes of ruminants, chiefly cows and sheep (European Commission, 2015).

As noted by Sadowski (2016), the result of impact of climate change on the agricultural sector in Poland will be a resultant of positive and negative changes (see Box 1). Because many of the estimated climate parameters (e.g. total precipitation or monthly temperature) is characterised by very broad confidence intervals, the final effect of climate change impact is rather difficult to be determined.

Box 1

Climate change impact on agricultural production - the case of Poland

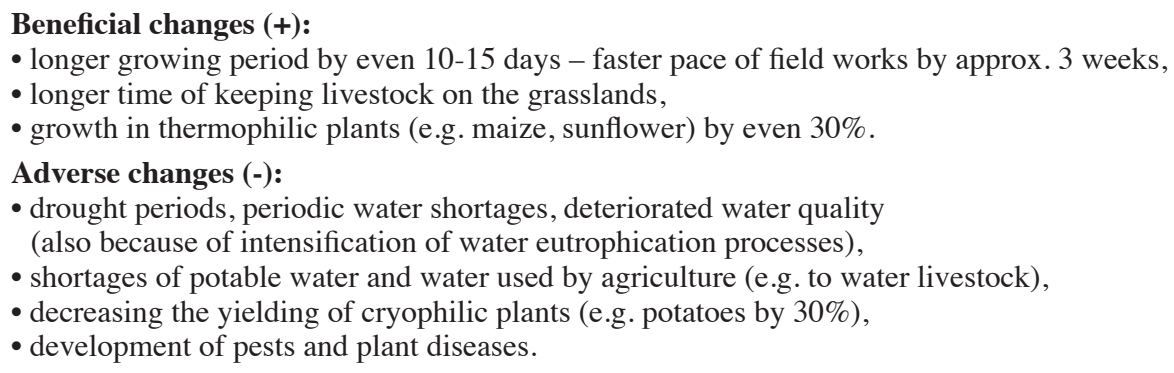

Source: own study based on Sadowski, 2016, pp. 5-7.

From the research of the interdisciplinary team of Zeijst (Zeijst et al., 2011) it follows that greening, which was incorporated into CAP 2014-2020, favours growth in biodiversity of rural ecosystems. According to the estimates of the above-mentioned scientists, it is expected that the biodiversity of organisms associated with agricultural production will increase by $3 \%$. It should be noted, though, that there is a trade-off between greening and decreasing agricultural production volume (in the EU-28 countries). In the opinion of Zeijst et al. (2011), given great differences between regional units of Member States as regards intensity level of agricultural production, the average amount of agricultural income or present actions under the $1^{\text {st }}$ and $2^{\text {nd }}$ pillar of CAP, it would be justified to design agricultural policy instruments at the regional level, instead of one-sizefits-all approach. For example, in regions dominated by extensive production type it would be expedient to keep the advantages of UAA with high biodiversity level. There are some possibilities of limiting the negative impact of greening on farm productivity. This refers, e.g., to the construction of the so-called green infrastructure at the regional level or to the use of agri-environmental measures for UAA, characterised by poorer fertility or unfavourable water relations.

The concept binding the challenges posed to the EU agriculture by the competitive forces on the agricultural markets with the need to sustain the paradigm 
of durable development is sustainable intensification (SI). Its assumptions were developed in the beginning mainly for the needs of developing countries. According to FAO, sustainable intensification as regards natural resources management (not only in agriculture but also forestry and aquaculture) refers to: (1) increased productivity, better efficiency of resources use, i.e. land, water, fodder and energy; (2) greater benefits for the environment; (3) better economic viability and elasticity of farms against economic crises; (4) stronger social acceptance in keeping with the principles of equality, not violating the rights of the others (FAO, 2015). This type of intensification consists in selection of such agro-technical and zoo-technical practices focused on improved productivity, which will take into account the "triad" of sustainability objectives (Ripoll-Bosch et al., 2012; Franks, 2014, Buckwell et al., 2014) ${ }^{5}$. The SI concept, provided that the measurement, assessment and control apparatus will be improved at the micro level, can contribute to deeper integration of the goal of ensuring food security with the existing environmental and ecological constraints (Soliwoda, 2015). This is indicated, for instance, by the comprehensive analysis of many measures allowing to adapt (at the micro level) to the climate change (see Box 2).

Box 2

Progress in agricultural production considering adaptation to climate change

\section{Changes to plant production}

- Focusing actions on improved efficiency of use of nitrogenous fertilisers (concerns e.g. "better technologies of nitrogen use", adjustments of supply in macroelement to plant needs),

- Application of fertilisation plans,

- More intensive use of crop rotation,

- Use of undersown crops,

- Use of no-tillage technique,

- Better efficiency of drainage techniques,

- Higher biomass carbon fixation rate, e.g. by higher amount of humus in the soil used for agricultural purposes, support to multiannual crops (orchards, nurseries of ornamental plants) here a decisive role is played by woodlots, environmental focus areas and permanent grasslands.

\section{Changes to livestock production}

- Modern animal feeding techniques (e.g. by better balancing of feed doses, which ensures better use of fodder, including elimination from the feed doses of unnecessary amounts of aminoacids and adding to the fodder preparations binding nitrogen compounds which are the source of $\mathrm{N}_{2} \mathrm{O}$ emissions),

- "Better livestock farming systems", e.g. by using biotechnological parameters reducing the $\mathrm{N}_{2} \mathrm{O}$ emission (added to faeces and litter) as well as "reducing the evaporation area of faeces from bedding and litter",

- Reducing emission from the stored slurry and manure.

Increased use of bioenergy and better energy efficiency

- Promoting the use of renewable energy sources (RES) considering the local needs,

- Implementing energy efficient investments in agriculture.

Source: adapted from Staniszewska, 2013.

\footnotetext{
${ }^{5}$ Results of empirical research conducted on the basis of a non-probable sample of British farmers were quite optimistic: farmers successfully managed to implement the targets of sustainable intensification, additionally farmers could reduce production costs (Firbank, Elliott, Drake, Cao and Gooday, 2013).
} 
Added value of CAP is its legislative "hedging" which is targeted at mitigation of the negative impact of the agricultural sector on the environment. This refers to e.g. greening of payments under the 1st pillar of CAP (Medarova-Bergstrom et al., 2012): i.e. diversification of crops, keeping permanent grasslands and Ecological Focus Areas (EFA). It should be added that this is a mandatory component of the direct payment scheme CAP 2014-2020, whose financing took up 30\% of the national financing envelope (for Poland - approx. EUR 1 billion) ${ }^{6}$. Basically a part of the contribution from the European Agricultural Fund for Rural Development (EAFRD) is allocated e.g. to mitigation of climate change by agri-environmental measures, payments to organic farming and farming in less-favoured areas (European Commission, 2016). Another initiative is the aforementioned European Innovation Partnership for agricultural productivity and sustainability (i.e. EIP-Agri). Hart, Baldock and Buckwell (2016), stressing the positive effects of the aforementioned strictly ecological measures, point to the ongoing debate between different organisations: whether the public funds going to farmers actually multiply the added value or do they rather lead to the so-called greenwashing effect. Wieliczko (2016) stated that the process of CAP inclusion into the effort of reducing GHGs emissions should be prudent and cautious (which follows from the problem of "outflow"). She recommended relevant bundles of CAP instruments (both under the 1 st and the 2nd pillar), i.e. greening of payments, agrienvironment-climate measures as well as instruments of the national agricultural policy (i.e. development of education, agricultural advisory, selected tax policy instruments). Grochowska (2016), considering the trajectories of CAP development, stated that as of 2007/2008 the concept of the so-called neo-productivism is predominating. It attempts at reconciliation of the contradictory ideas of "multifunctional agriculture" and "productive agriculture". However, Grochowska (2016) has justified doubts concerning the possibility of "integrating production targets with environmental ones". She argues that "(...) it is rather a modification of practices which were based on an industrial model of agriculture".

\section{Dilemmas involved in provision of public goods}

Given the EU targets regarding the agricultural sector, it seems that CAP is conductive to support to generation of public goods, including above all food security. Efficiency of implementation of one of the basic objectives of the Treaty concerning the EU agricultural policy, i.e. ensuring food supplies at affordable prices for the citizens, is clear be it only from the fact that in the Global Food Security Index ranking for 2016 as many as six out of ten first countries are the EU Member States ${ }^{7}$ (foodsecurityindex.eiu.com).

\footnotetext{
${ }^{6}$ It should be added that the Polish RDP 2014-2020 enables diversification of crops by an equivalent practice under agri-environment-climate measure.

${ }^{7}$ The index considers a number of parameters concerning: physical accessibility, financial accessibility and food quality.
} 
Moreover, CAP increasingly more intensively supports measures to generate public goods. This takes place mainly in the 2nd pillar, under which farmers can voluntarily take up specific agricultural measures and practices favourable to the environment and for that they receive compensation of incurred costs. In the present programming period, this refers mainly to the following instruments: "Agri-environment-climate measures" and "Organic farming". At the same time, the process of creating public goods involves the key CAP instrument, i.e. direct payments. Initially, their role in creating public goods was limited to cross-compliance principles. The currently applicable payment scheme covers additional tools to protect the environment, especially biodiversity, which include the aforementioned greening of payments, i.e. granting a special payment for practices beneficial to the climate and the environment ${ }^{8}$.

Furthermore, support for rural areas development, including ensuring their viability, has the form of subsidisation of public goods and not only a small group of beneficiaries. Increase in attractiveness of rural areas as a place of residence and running business activities favours territorial cohesion of the EU and this contributes to a more sustainable development of the entire area of the Community. Moreover, support to the development potential and bottom-up approach to rural areas development both have the character of instruments acting directly on all residents covered with support and indirectly on other EU citizens benefiting e.g. from development of tourist attractiveness of rural areas or enjoying socio-cultural benefits linked to preserving cultural heritage of rural areas.

Because of a regular increase in CAP engagement in measures to protect the environment, beneficiaries of the policy increasingly more become citizens of the EU. Nonetheless, doubts can be raised as regards efficiency of the currently incurred expenditures for the purpose. Therefore, it is necessary to monitor the effects of implemented instruments and in the subsequent reforms introduce more efficient and effective instruments. In case of public goods, result-related payments for implemented agricultural practices seem to be such a solution (Lankoski, 2016), but even they have their limits, which include, above all, cost and difficulties in their measurement (Kulawik, 2016).

\section{Multiplier effects}

In general, multiplier effects refer to a situation when one support entity leads to production generation or income higher by over one unit. However, in case of agriculture strongly involved in natural resources management, the estimate of scale of the existing multiplier effects has to take account of the environmental issues, and due to the fact that CAP implements also social objectives - referring for instance to keeping the viability of rural areas, it also has to consider the social aspects.

\footnotetext{
${ }^{8}$ At this point, what should be mentioned is the criticism of the finally accepted form of greening and calls to increase the positive impact of the instrument on the environment in the next programming period (e.g. Matthews, 2016).
} 
At the same time, as regards support offered from the EU funds multiplier effects or leverage effects are referred to in the context of involvement of funds coming from other sources - both private and public, from budgets of Member States. This understanding of the approach to analysis of the EU support scale of impact is particularly strongly highlighted recently in relation to the policy of investment stimulation in the EU, which was announced in the European Commission Investment Plan for Europe, also known as Juncker Plan, the European Fund for Strategic Investments related thereto. The drive at increasing the level of investments in the EU by higher involvement of the financial sector concerns also agriculture. Already from the 2007-2013 programming period, Member States may - under their rural development programmes - introduce financial instruments, such as loan guarantees or subsidies to interest on loans, which are to facilitate access to bank loans to farmers. These instruments can be used also in the current programming period, but they are still not very popular and were included in rural development programmes of only few countries and regions ${ }^{9}$. Implementation of such instruments may give major multiplier effects. They cover money multiplier, catalytic effect and Keynesian multiplier and accelerator (Fig. 2).

The actual level of the leverage effect connected to the use of the EU funds to provide loan guarantees to farmers and small and medium-sized entrepreneurs, running economic activity in rural areas, shows an example of a guarantee fund created by Romania. Between 2010 and 2014, the leverage effect for the funds from the European Agricultural Fund for Rural Development amounted to 4.58, which means that beneficiaries were granted that much more funds in the form of loans. Whereas, the multiplier referring to the total amount of involved public funds - coming from the EU budget and the Romanian budget - reached 3.6. Simultaneously, rate of reinvestment of funds from the EU was $90 \%$ (European Investment Bank, 2015). These results attest to the fact that the financial instruments can foster efficient support to farmers in reaching for loans for investments.

Common Agricultural Policy contributed to agriculture development, ensuring food production. Thus, Poland is self-sufficient and does not have to depend on other countries in case of a possible crisis. The scope of allocation possibilities depends on the status of technique and on the size of resources in the economy. Therefore, subsidisation of agriculture under CAP allows to invest in new techniques and technologies, and in resources improving production efficiency. The scale effect consists in the fact that the more is produced and sold, the lower can be the product price. This is facilitated by financial aid programmes for the

\footnotetext{
${ }^{9}$ In the first draft of RDP approved by the European Commission only eight from one hundred and fifteen programmes provide for implementation of financial instruments. The programmes cover the following countries or regions: England (Great Britain), Aragon (Spain), Castilla y Leon (Spain), Lombardy (Italy), Venetia (Italy), Tuscany (Italy), Basse-Normandie (France), Slovenia and Hungary (Kantor Management Consultants S.A., 2015).
} 
agri-food sector and rural areas. When the production and sales are higher, it is possible to buy raw materials at lower prices, apply newer techniques and technologies and automatize production, and also to reduce unit costs of sales. To benefit from the scale effect, a company has to have a large outlet market for its products. CAP makes it possible to meet this condition.

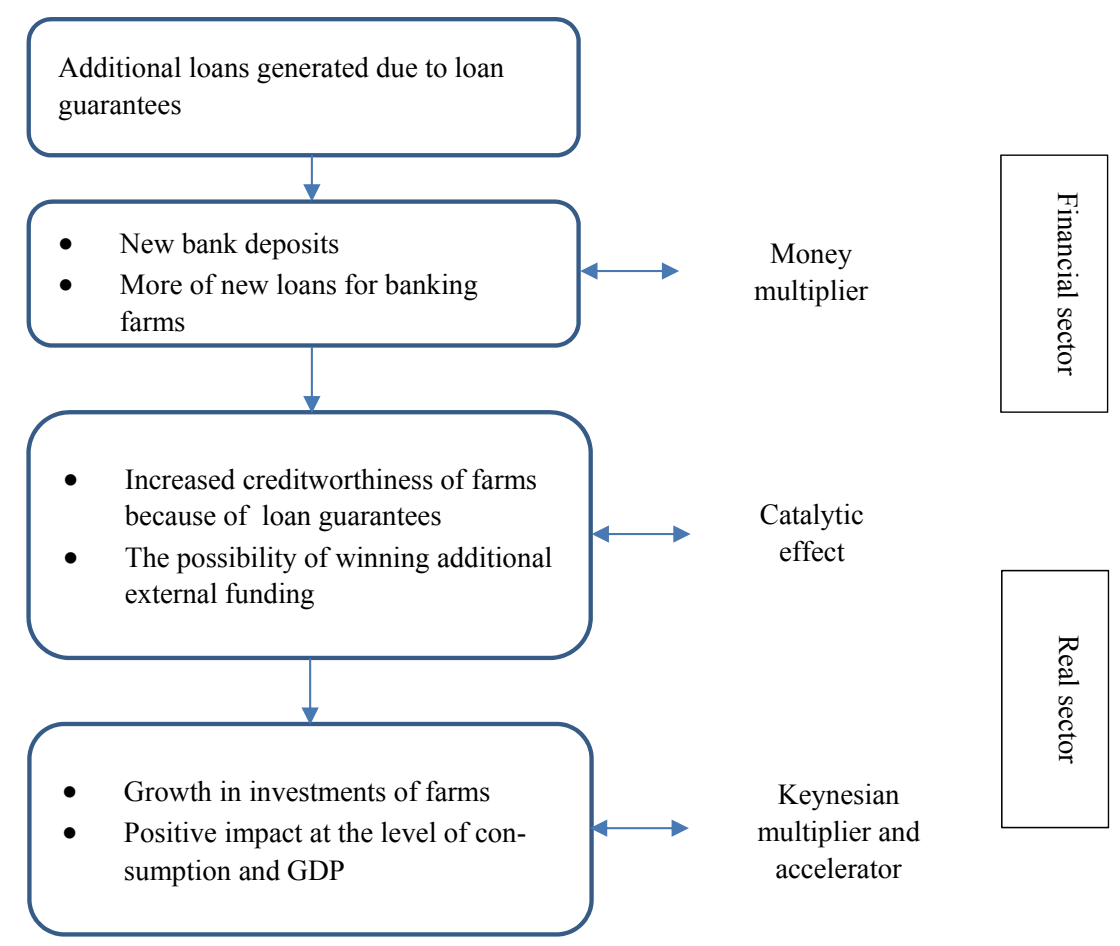

Fig. 2. Multiplier effects involved in loan guarantee provided under CAP instrumentation. Source: own study based on (European Commission, 2013).

Emergence or development of agricultural activity at a given area can lead to a growth in income and employment in many other enterprises. This may also contribute to higher tax receipts of local authorities. Such an increase is termed as multiplier effect and its size allows to assess the impact of a given agricultural activity on functioning of other enterprises in its surrounding. The multiplier effects are the result of additional demand created by newly established or developing entities. This results from a growth in the number of enterprises supplying goods and services for the farms. The multiplier effects can also be the result of higher purchasing power of the population by remunerating employees, which leads to development of enterprises satisfying the consumer needs. Develop- 
ment of agriculture through the medium of an additional demand for products and services thus influences better business cycle at other enterprises, which in turn boost demand leading to subsequent cycles of multiplier effects. Because farms and their employees pay taxes, development of the entities contributes to a growth in state budget incomes and also incomes of municipalities (gminas) and districts (poviats).

Multiplier effects increase demand for unqualified labour force to work in non-agriculture activity, thereby mitigating poverty in rural areas (Snodgrass, 2014). The existence of a multiplier effect strengthens arguments for investments in agriculture and elimination of the urban approach in governmental policies. The multiplier effect largely follows from market failures and unused resources. In case of a more integrated economy, in which markets function better, the value of the multiplier will probably decrease. In a longer perspective, the positive externalities can become the most important political implication of the multiplier effect. To implement this potential, it is necessary to improve the market environment of agriculture and industry, with which these are connected, and thus to improve communication, ensure more favourable conditions for running business activity and increase confidence among participants of trade transactions. It is also necessary to strengthen connections between farmers and the global value chains and national and foreign investors (Snodgrass, 2014). This should be the main goal of CAP.

Funds obtained by Poland in 2004-2013 under the Common Agricultural Policy improved the condition of our agriculture. All voivodeships (regions) noted a major growth in gross value added per capita of an agricultural employee, although the share of the sector in employment decreased over the same time. This means that a smaller number of people produced a higher value, which was possible mainly due to higher efficiency. Each voivodeship recorded also a growth in an average farm size and almost all of them in utilised agriculture area (UAA) per capita. Hence, farm fragmentation - so very typical of Poland decreased (Lenkiewicz, Rokicki and Wieliczko, 2014).

\section{European added value in the CAP budget perspective}

There is no convincing and sufficient evidence that the costs of subsidies are, or at least could be, lower, if agricultural policy had been implemented at the national and not Community level. However, the idea of the CAP does not stem from the desire to minimise operating costs, but from the will to cooperate in order to create as uniform as possible conditions for agricultural activity for all farmers in order to facilitate operation of the EU single market for agricultural products. This was the very reason behind a strong effort of the European Commission during the last reform to create a single set of practices favourable for the environment, which would form grounds for the so-called greening of direct payments. To verify the above statements, a counterfactual analysis should 
be conducted ${ }^{10}$. Countries of limited central budgets (e.g. "new" EU Member States) would have serious difficulties in keeping financial support under the agricultural policy instruments at the current level. What could be considered, is competition based on low costs of factors of production (e.g. labour - Ukraine) or deeper intensification coupled with progress with innovation (e.g. the Netherlands). Although the US eliminated direct payments from the Farm Bill 2014, but production risk management instruments and anticyclical instruments are still kept in place. It is expected that British farms without the former support from the CAP, will lose their economic viability and national subsidies - probably much lower than the EU ones - will only be remuneration for provision of public goods (Gierling, 2016). However, the example of agricultural policy reform in New Zealand (mid-1980s) shows that in case of agriculture based on large size entities restriction of financial interventionism was to hypothetically result in cessation of activity of over $10 \%$ of farms and actually it was only $1 \%$ of farms (Gierling, 2016). If the former agriculture support scheme ${ }^{11}$, built by CAP, would have been suspended or eliminated this could result in an increase in social costs, disproportionate to the potential effects at the level of national budgets (CAP, 2020, 2016).

In conclusion it may be stated that the Common Agricultural Policy, in a way, contributes to ensuring allocation efficiency, scale effects and multiplier effects. The funds allocated to agriculture are a good investment, since they foster agriculture development and thus food production.

\footnotetext{
${ }^{10}$ Ragazzi, Pavone and Sella (2015) held a counterfactual analysis, which was aimed at determining the net effect of subsidies under the 2 nd pillar of CAP. The research covered agri-food companies in the Piemont region (north-western Italy), which applied Measure G, targeted at increase in the value added of agri-food products. The applied research approach involved comparison between economic efficiency of the target group of agri-food enterprises benefiting from the support under RDP and the entities not covered by this type of subsidisation. The evaluation carried out in 2010 showed that there exists the "picking the winner effect". This actually means that enterprises, which in the CAP 2000-2006 programming period obtained the best economic and financial results, maintained their position also in the next CAP seven-year period (2007-2013). State aid was most often used by entities with major competitive capacities.

${ }^{11}$ It should be emphasised that there are negative - from the perspective of social welfare - effects, which include social deadweight loss or subsidy leakage. The micro-economic grounds of "loss of social wellbeing" (on a graphic model presenting the effects of introducing price support) were discussed by Wichern (2004). The empirical verification done by Michalek, Ciaian and Cancs (2013), is based on the method of Propensity Score Matching (PSM). The aforementioned three researchers tried to assess to what extent public support under RDP can have a complementary and substitutive effect on investments of dairy farms in the German land of Schleswig-Holstein. To implement the research objective the aforementioned researchers approximated the social deadweight loss and on this basis they determined to what extent farmers would make similar investment decisions, but without support under the RDP. It was stated that the social deadweight loss accompanying financial support under the RDP was close to nearly $100 \%$. This means that investment projects at these dairy farms could have been implemented without support instruments under the RDP. It should be noted that the scope of research was narrowed down to one German region only and to farms specialising in milk production. It was not empirically confirmed that the researched farms would be able to postpone the planned investments to a later period (the so-called inter-temporal substitution).
} 


\section{Current socio-economic challenges facing the EU}

Although the CAP refers to the original and fundamental challenge facing humanity from the beginnings of time, i.e. food security, it is not its basic drawback. Indeed, today this is not a problem as grave as the inflow of migrants from non-EU countries to the EU or terrorism, but these are, nonetheless, issues which require action already today, as part of a long-term Community development strategy.

Good quality food production and economic existence of the European farms are certainly proofs of CAP success as a transnational agricultural policy (and actually agri-food policy). Otherwise the issue of providing affordable food products to the EU consumers could become another difficult problem (it needs to be kept in mind that food issues are the challenge of the so-called Third World countries). The current issues are solved at the EU forum under ad-hoc decisions. Some synergy effects can be tied to interaction between the cohesion policy and CAP in the context of socio-demographic problems on rural areas. There are, however, some interlocking areas, but the CAP cannot be treated as a universal remedy, or even a panacea to all issues, including political and social ones, which the EU countries have to face today. Matthews (2015), considering the possible form of CAP 2020+, draws attention to the WTO pressures concerning the status of the "greenbox" single area payment. Moreover, it might be expedient to rethink the interactions between the climate-energy package and CAP instruments (e.g. connected to support to energy crops, issue of GHGs emissions from the agricultural sector) (Matthews, 2015). Such argumentation is an evidence of unfamiliarity with realities of the current economic policymaking, which has to consider e.g. conditions and limits following from globalisation, simultaneously lacking institutional solutions and political will to solve transnational and global problems in a coordinated manner. In this context, it needs to be remembered that CAP is still, above all, a sectoral policy. Thus, the overall socio-economic problems have to be solved, first and foremost, by relevant policies. Presently, it is not easy, which is evidenced by non-standard actions of key central banks of the world. It suffice to say that currently approx. $1 / 4$ of the global GDP is created in countries where banks use negative interest rates. CAP and the national agricultural policies should not lose from sight the fact that they ought to also contribute to the implementation of objectives which contemporary western democratic societies set for themselves. This refers to: freedom, equity, safety and progress.

In the report Global Europe 2050, drawn up at the request of the European Commission bodies, as much as 9 EU development scenarios were presented describing in detail three of the most contrasting and most probable options (European Commission, 2012). Attention should be drawn to the scenario known as the "EU Reneissance", which considers the need for smart and sustainable growth or fiscal and financial consolidation, or even an in-depth integration of 
political structures. Mirkowska and Józwiak (2014), based on analysis of conclusions from the aforementioned report, rather pessimistically infer that the EU facing very serious threats linked to the migration pressure, separatist tendencies, even in countries forming its core (i.e. the EU-15), is not seen as a common value standing beyond the narrow and particular interests of the nations.

Table 2 presents key changes proposed in the EU budget for 2017 (compared to the last year's budget). On September 12, 2016 the European Union countries agreed to cut the funds in next year's EU budget allocated to less-developed regions of the block, mainly in the east (including Poland), at the same time, increasing spending on migration flow management and boosting growth. In an unprecedented migration wave noted last year, 1.3 million people reached the south coasts of the EU heading from Greece and Italy mainly to Germany. The proposal of the European Commission to increase the funds for solving the migration crisis in the EU budget for 2017 was fully supported by governments of Member States. European Commission, planning a regular review of the EU financial framework for 2014-2020, can thus suggest a more flexible budget accommodating priorities in case of emergency situations and reducing fixed costs. Some experts see the form of the budget draft as a possible punishment for Eastern European countries that objected to the EU plan of reallocation of immigrants to all 28 Member States, which failed (no numerical targets have been reached). However, the Eastern European countries adopted the proposed budget, which includes also a reduction in the expenditures in many sectors, including agriculture and research. Cuts in funds for the poorer regions, the largest of all budget expenditure headings, are caused by longer periods needed by regional administration to launch development projects. Usually, the values of using these funds grow closer to the final stage of the EU long-term budgets. Funds for the EU space projects were also decreased; these projects included Galileo satellite navigation programme, programmes for farmers and programmes linked to nuclear power, such as ITER nuclear fusion reactor (Reuter World News, 2016; The Observer, 2016). As far as migration crisis in Europe can be considered as an exogenous factor causing erosion of the European added value because of the income loss in the Community budget, the adopted proposals of changes are crucial to allow the EU to return to the path of longterm growth and development. 
Table 2

The EU budget for 2017 in the context of European added value

\begin{tabular}{|c|c|c|}
\hline Category & Value & Comments \\
\hline Migrations & EUR 5.91 billion & $\begin{array}{l}\text { It can be noted that there was a nearly } 25 \text { per cent growth } \\
\text { in expenditure on migration and security against this } \\
\text { year's budget - as per calculations of the EU Council } \\
\text { of } 12.09 .2016 \text {. These funds would be allocated to } \\
\text { strengthening external borders, resettlement of asylum } \\
\text { seekers and integration of immigrants. }\end{array}$ \\
\hline $\begin{array}{l}\text { Removing the } \\
\text { reasons for flow } \\
\text { of migrants }\end{array}$ & EUR 2.2 billion & $\begin{array}{l}\text { The need to finance the EU external measures to eliminate } \\
\text { the reasons for migration flows. }\end{array}$ \\
\hline $\begin{array}{l}\text { Promoting } \\
\text { economic growth } \\
\text { and job creation }\end{array}$ & EUR 21.3 billion & $\begin{array}{l}\text { Approx. } 9 \text { per cent growth in expenditure for projects } \\
\text { aimed at growth promotion and job creation were planned. }\end{array}$ \\
\hline $\begin{array}{l}\text { Reducing the } \\
\text { unemployment } \\
\text { rate among youth }\end{array}$ & EUR 0.5 billion & $\begin{array}{l}\text { Additionally, funds for the so-called solidarity package } \\
\text { - strengthening the role of NGOs and pilot programme } \\
\text { helping people below } 30 \text { to travel around the EU } \\
\text { countries. }\end{array}$ \\
\hline $\begin{array}{l}\text { Common } \\
\text { Agricultural } \\
\text { Policy }\end{array}$ & EUR 42.6 billion & $\begin{array}{l}\text { A probable growth in the expenditure on RDP by the end } \\
\text { of this decade. }\end{array}$ \\
\hline The EU budget & $\begin{array}{l}\text { Total liabilities: EUR } \\
157.88 \text { billion } \\
\text { Total payments: EUR } \\
134.49 \text { billion }\end{array}$ & $\begin{array}{l}\text { Cuts were deeper by over EUR } 820 \text { million against } \\
\text { the proposal of the Commission, even more reducing } \\
\text { the expenditure on the poorer regions, which has already } \\
\text { been suggested by the EU executive authority. }\end{array}$ \\
\hline
\end{tabular}

Source: own study based on Reuter World News, 2016; The Observer, 2016.

\section{Conclusions}

The European added value is still a rather blurred category, vague and more descriptive than captured in precise calculation scheme. This definitely differentiates it from added value in economy and finances and most certainly follows from complexity of the EAV, but even more from the fact that the EU still has problems with specification of the principle of subsidiarity and principles of clear separation of local, regional, national and transnational externalities related thereto from pure public goods. This, in line with the logic of fiscal federalism, should be followed by symmetrical matching of the financing source of internalisation of externalities and provision of the aforementioned goods. In practice, such proportionality has not been fully used, because it was possible to implement the budget equity (cohesion policy) or a given sectoral policy considered as the Community policy (CAP) by financing it almost completely from the EU funds. Now, budget equity is increasingly more contested by the net payers, claiming that the net beneficiaries do not show equity in other areas, especially 
as it comes to tackling the immigration crisis. In the changing external environment, fraught with threats, uncertainties and risk, CAP has to more and more often compete for public funds with internal security, fight against terrorism, the need to strengthen the EU external borders and assimilation of immigrants, common defence policy or economic growth stimulation. Therefore, arguments for further CAP budget financing have to be increasingly more subtle and based on hard facts referring also to the countryside and other food chains and not only agriculture. At the present moment, EAV only partly fulfils the function.

To prevent a situation when EAV is seen as a new form to old contents, other conditions also have to be met. It is vital to convince the Europeans that CAP and cohesion policy allow the Community as a whole, respective Member States, regions, economic entities and regular citizens to develop, become more innovative, creative and competitive and can combine the national and European identity. Therefore, the EU has to mitigate the fears of the Europeans linked to the existing practice of globalisation. It also needs to be proved that sustainability can be reconciled with flexibility, greater resistance to shocks, satisfactory efficiency, productivity and competitiveness. Moreover, it is necessary to show actual examples of successful transitions to low-carbon economy and circular economy, tangible benefits from distributed and hybrid energy generation, real possibilities of adaptation to climate change and counteracting climate change, the meaning of intergenerational optimisation of renewable and non-renewable natural resources. It is also necessary to convince the Europeans that selective inclusion of immigrants can bring visible economic effects in the form of greater innovation and productivity. From the above, it clearly follows that a rather full reference to EAV goes beyond the limits of CAP and should be the subject of interdisciplinary analyses. 


\section{Literature:}

Baldock, D., Buckwell, A., Colsa-Perez, A., Farmer, A., Nesbit, M., Pantzar, M. (2016). The potential policy and environmental consequences of a UK departure from the European Union. Report by the Institute for European Environmental Policy in collaboration with the Wildlife Trusts, the Royal Society for Protection of Birds, and WWF UK.

Bennetzen, E.H., Smith, P., Porter, J.R. (2016). Agricultural production and greenhouse gas emissions from world regions - The major trends over 40 years. Global Environmental Change, vol. 37, pp. 43-55.

Buckwell, A., Uhre, A.N., Williams, A., Polakova, J., Blum, W.E.H., Schiefer, J., Lair, G.J., Heissenhuber, A., Schie $\beta$, P., Kramer, Ch., Haber, W. (2014). The Sustainable Intensification of European Agriculture. A Review sponsored by the Rise Foundation.

CAP 2020 (2016). CAP greening: what are its environmental prospects. Retrieved from: http://cap2020.ieep.eu/2016/1/21/cap-greening-what-are-its-environmental-prospects? (access date: 19.07.2016).

Ciliberti S., Frascarelli A. (2015). A critical assessment of the implementation of CAP 20142020 direct payments in Italy. Bio-based and Applied Economics, 4(3), 2015, pp. 261277.

EU Observer (2016). EU reinforces 2017 budget on migration and jobs. Nov. 17, 2016. Brussels. Retrieved from: https://euobserver.com/institutional/135937.

European Climate Adaptation Platform (2016). Agriculture. Retrieved from: http://climate-adapt.eea.europa.eu/eu-adaptation-policy/sector-policies/agriculture.

European Commission (2001). Ex ante Evaluation. A Practical Guide for Preparing Proposals for Expenditure Programmes.

European Commission (2012). Global Europe 2050. Retrieved from: https://ec.europa.eu/ research/social-sciences/pdf/policy_reviews/global-europe-2050-report_en.pdf (access date: 19.07.2016).

European Commission (2013). Commission Staff Working Document. Ex-ante assessment of the EU SME Initiative. SWD (2013)517 final.

European Commission (2015). EU agriculture and climate change. Retrieved from: http:// ec.europa.eu/agriculture/sites/agriculture/files/climate-change/factsheet_en.pdf.

European Commission (2015). EU agriculture spending focused on results. Retrieved from: http://ec.europa.eu/agriculture/cap-funding/pdf/cap-spending-09-2015_en.pdf.

European Commission (2016). European Innovation Partnership "Agricultural productivity and Sustainability” EIP-AGRI. Retrieved from: http://ec.europa.eu/agriculture/research-innovation/eip-agriculture_en.

European Commission (2016). Greening. Retrieved from: http://ec.europa.eu/agriculture / direct-support/greening_en.

European Investment Bank (2015). Rural Credit Guarantee Fund. Case Study. Luxembourg: European Investment Bank.

Eurostat (2016). International trade in goods. Retrieved from: http://ec.europa.eu/eurostat/ statistics-explained/index.php/International_trade_in_goods.

Ferrer, J.N., Kaditi, E.A. (2008). The EU added value of agricultural expenditure - from market to multifunctionality - gathering criticism and success stories of the CAP. Report prepared by the Centre for European Policy Studies (CEPS) for the European Parliament. 
Figueira, F. (2009). How to Reform the EU Budget? A Methodological Toolkit. Stockholm: Swedish Institute for European Policy Studies.

Firbank, L.G., Elliott, J., Drake, B., Cao, Y., Gooday, R. (2013). Evidence of sustainable intensification among British farms. Agriculture, Ecosystems and Environment, 173, 1 July 2013, pp. 58-65.

Franks, J.R. (2014). Sustainable intensification: A UK perspective. Food Policy, 47, August 2014, pp. 71-80.

Gierling, J. (2016). Agriculture. Retrieved from: http:/www.juliegirling.com/wp-content/ uploads/2015/10/Agriculture.pdf (access date: 19.07.2016).

Grochowska, R., (2016). Paradygmat bezpieczeństwa żywnościowego w polityce rolnej Unii Europejskiej. Seminarium IERiGŻ-PIB, Warszawa, 16.11.2016. Retrieved from: http:// ierigz.waw.pl/download/20179-seminarium_IERIGZ.pdf.

Hart, K., Baldock, D., Buckwell, A. (2016). Learning the lessons of the Greening of the CAP, a report for the UK Land Use Policy Group in collaboration with the European Nature Conservation Agencies Network. Institute for European Environmental Policy, London.

Kantor Management Consultants S.A. (2015). Synthesis of Ex-Ante Evaluations of Rural Development Programmes 2014-2020. Final Report. Luxembourg: Publications Office of the European Union.

Kulawik, J. (2016). Wybrane aspekty ekonomiczno-fiskalne zrównoważenia i wielofunkcyjności wsi i rolnictwa. Warszawa: IERiGŻ-PIB.

Lankoski, J. (2016). Alternative Payment Approaches for Biodiversity Conservation in Agriculture. OECD Food, Agriculture and Fisheries Papers, No. 93, OECD Publishing, Paris.

Lenkiewicz, S., Rokicki, B., Wieliczko, B. (2014). Budżet rolny a konkurencyjność polskiego rolnictwa. Warszawa: IERiGŻ-PIB.

Matthews, A. (2015). Reflections on the CAP post-2014. In: J. Swinnen (ed.), The Political Economy of the 2014-2020. Common Agricultural Policy. An Imperfect Storm (pp. 493-508). Centre for European Policy Studies (CEPS), Brussel/Rowman and Littlefield International, London.

Matthews, A. (2016). The future of direct payments. In: Research for AGRI Committee CAP Reform post-2020 - Challenges in Agriculture. Brussels: European Union.

Medarova-Bergstrom, K., Volkery, A., Baldock, D. (2012). Criteria for maximising the European added value of EU budget: the case of climate change. Brussels: IEEP.

Metis, WIFO, AEIDL (2014). Investment Support under Rural Development Policy Contract 30-CE-0609852/00-41. Final Report. Luxembourg: Publications Office of the European Union.

Michalek, J., Ciaian, P., Kancs d'A. (2013). Firm-level evidence of deadweight loss of investment support policies: a case study of dairy farms in Schleswig-Holstein. IATRC 2013 Symposium: "Productivity and Its Impacts on Global Trade" co-sponsored by the IATRC and the European Commission. 2-4 June, Seville.

Mirkowska, Z., Józwiak W. (2014). Rozwój gospodarki świata i UE w perspektywie długoterminowej. Miejsce sektora rolnego. In: R. Grochowska (ed.), Kierunki rozwoju rolnictwa i polityk rolnych (Synteza) (pp. 78-95), Program Wieloletni 2015-2019, No. 127. Warszawa: IERiGŻ-PIB. 
Molino, E., Zuleeg, F. (2011). The EU Added Value Test to Justify EU spending: What Impact for Regions and Local Authorities? European Policy Centre.

MRiRW(2016).Materiał informacyjny dotyczący płatnościztytułupraktyk rolniczychkorzystnych dla klimatu i środowiska (Zazielenienie). Warszawa, March 2016. Retrieved from: http://www.minrol.gov.pl/content/download/49161/270533/version/16/file/Zazielenienie-za\%C5\%82\%C4\%85cznik\%201.pdf (access date: 19.07.2016).

Perman, R., Ma, Y., Common, M., Maddison, D., McGilvray, J. (2011). Natural Resource and Environmental Economics ( $4^{\text {th }}$ Edition). London/New York: Pearson.

Ragazzi, E., Pavone, S., Sella, L. (2015). Supporting agro-food enterprises in Piedmont: a counterfactual analysis. XIII Workshop Annuale della Società Italiana di Economia e Politica Industriale.

Report of the Presidency Conference on the Multiannual Financial Framework (MFF). 28 January 2016, Amsterdam.

Reuters World News (2016). EU to slash funds to Eastern Europe to step up migration budget. September 12, 2016, Brussels. Retrieved from: http://www.reuters.com/article/useu-budget-migration-idUSKCN11I1X9.

Ripoll-Bosch, R., Díez-Unquera, B., Ruiz, R., Villalba, D., Molina, E., Joy, M., Olaizola, A., Bernués, A. (2012). An integrated sustainability assessment of Mediterranean sheep farms with different degrees of intensification. Agricultural Systems, 105, Issue 1, January 2012, pp. 46-56.

Sadowski, M. (2016). Ocena potencjalnych skutków społeczno-gospodarczych zmian klimatu $w$ Polsce. WWF. Retrieved from: http://awsassets.wwfpl.panda.org/downloads/analiza_zmiany_klimatu_polska.pdf.

Snodgrass, D. (2014). Agricultural transformation in sub-Saharan Africa and the Role of the Multiplier: A Literature Review. USAID LEO, Report No. 4.

Soliwoda, M. (2015). Dylematy wokół wymiaru finansowego zrównoważenia gospodarstw rolniczych. Zagadnienia Ekonomiki Rolnej, No. 3(344), pp. 112-128.

Staniszewska, M. (2013). Wpływ rolnictwa na zmiany klimatu. Dla Klimatu - program klimatyczny Polskiej Zielonej Siecie. 19.12.2013. Retrieved from: http://dlaklimatu.pl/ wplyw-rolnictwa-na-zmiany-klimatu/.

Vullings, W., Arnold, E., Boekholt, P., Horvat M., Mostert B., Rijnders-Nagle M. (2014). European Added Value of EU Science, Technology and Innovation actions and EU-Member State Partnership in international cooperation. Main Report. Publications Office of the European Union, Luxembourg.

Vullings, W., Arnold, E., Boekholt, P., Horvat, M,. Mostert, B., Rijnders-Nagle, M. (2014). European Added Value of EU Science, Technology and Innovation actions and EU-Member State Partnership in international cooperation. European Commission, Directorate-General for Research and Innovation, International Cooperation 2014.

Wichern, R. (2004). Economics of the Common Agricultural Policy. Economic Papers, No. 211 August 2004, Directorate-General for Economic and Financial Affairs. Retrieved from: http://europa.eu.int/comm/economy_finance.

Wieliczko, B. (2016). Jak włączyć rolnictwo UE do wysiłku ograniczania emisji gazów cieplarnianych? Seminarium IERiGŻ-PIB, Warszawa, 2.12.2016. Retrieved from: http:// ierigz.waw.pl/download/20550-seminarium_BW.pdf. 
Wieliczko, B., Kurdyś-Kujawska, A., Herda-Kopańska, J. (2016). Mechanizmy i impulsy fiskalne oddziałujace na rozwój wsi i rolnictwa (2). Program Wieloletni 2015-2019, No. 34. Warszawa: IERiGŻ-PIB.

Zeijts, H. van (kier.), Overmars, K., Bilt W. van der, Schulp, N., Notenboom, J., Westhoek, H., Helming, J., Terluin, I., Janssen, S. (2011). Greening the Common Agricultural Policy: impacts on farmland biodiversity on an EU scale. The Hague: PBL Netherlands Environmental Assessment Agency. 


\author{
ALEKSANDER GORZELAK \\ JUSTYNA HERDA-KOPAŃSKA \\ JACEK KULAWIK \\ MICHAE SOLIWODA \\ BARBARA WIELICZKO \\ Instytut Ekonomiki Rolnictwa i Gospodarki Żywnościowej \\ - Państwowy Instytut Badawczy \\ Warszawa
}

\title{
KONTROWERSJE WOKÓŁ EUROPEJSKIEJ WARTOŚCI DODANEJ TWORZONEJ PRZEZ WPR
}

\begin{abstract}
Abstrakt
Poczawszy od wybuchu kryzysu finansowego na przełomie lat 2008/2009, UE weszła $w$ niespotykany $w$ dotychczasowej historii okres bardzo poważnych wstrzasów. Problemy te najpierw objęty gospodarke (słaby i bardzo zmienny wzrost, z okresami nawet płytkich recesji, wysokie bezrobocie, szczególnie wśród ludzi młodych), później sektor bankowy i budżety narodowe. W konsekwencji kilka starych krajów UE, należacych do strefy euro, stało sie $w$ istocie technicznie niewypłacalnymi. Na domiar złego, w pewnym momencie do południowej Europy zaczęła napływać wielka fala imigrantów, Rosjanie zajęli Krym, wybuchła wojna w Donbasie, a wybory w USA wygrat D. Trump, mogacy zdecydowanie osłabić NATO. W tym kontekście podejmowane różne próby rozwiązania tych minikryzysów czesto były spóźnione, mało odważne i niekonsekwentne. Nie może zatem zaskakiwać, że ostatecznie kryzys zaczą dotykać sfery społeczno-politycznej i instytucjonalnej, czego wyrazem jest pogłębiajaca się niewiara Europejczyków w instytucje wspólnotowe i demokrację liberalna. Stąd mamy rozpowszechniajacy się populizm, egoizm narodowy $i$ regionalny oraz tendencje dezintegracyjne. Zaowocowato to już Brexitem oraz obawami, że podobne decyzje moga podjać też inni członkowie Unii. Byłoby to równoznaczne z jej rozpadem. W tych warunkach przekonujace legitymizowanie dalszego trwania i rozwoju Wspólnoty wymaga obecnie wielkiego wysiłku intelektualnego, politycznego i organizatorskiego, a później znalezienia drożnych kanałów dotarcia z propozycjami, rekomendacjami i gotowymi rozwiąaniami aplikacyjnymi do jak najszerszego kręu odpowiedzialnych jej obywateli, by odzyskiwali wiare w sens projektu europejskiego i możliwość funkcjonowania w podwójnej tożsamości, narodowej i europejskiej. Idealnie byłoby, gdyby naprawa Unii uległa przy tym głębszej demokratyzacji, a więc realizowana była przy aktywnym współudziale Europejczyków, a nie wciaż przez techno- $i$ eurokratów. Jedna z ciekawszych w tym momencie koncepcji wydaje się być europejska wartość dodana, a więc - w dużym skrócie - pewna suma korzyści extra, uzyskiwanych z racji integracji $w$ porównaniu do efektów osiaganych $w$ ramach narodowej polityki społeczno-ekono-
\end{abstract}


micznej. Wartość tę można próbować opisywać, a w miarę możliwości także kwantyfikować, dla wszystkich obszarów integracji europejskiej. W artykule jednak ograniczono sie tylko do WPR, koncentrujac sie na kwestiach metodologicznych, środowiskowo-klimatycznych, innowacjach, inwestycjach oraz kompleksie kluczowych problemów budżetowych.

Słowa kluczowe: europejska wartość dodana, finanse rolnictwa, polityka środowiskowo-klimatyczna w rolnictwie, Wspólna Polityka Rolna.

Accepted for print: 10.04.2017. 